\title{
HYBRID-OPTIONAL EFFECTIVENESS FUNCTIONS ENTROPY CONDITIONAL EXTREMIZATION DOCTRINE CONTRIBUTIONS INTO ENGINEERING SYSTEMS RELIABILITY ASSESSMENTS
}

\author{
Goncharenko Andriy Viktorovich \\ Aerospace Faculty, National Aviation University, \\ Address: 1, Kosmonavta Komarova Avenue, Kyiv, 03058, Ukraine \\ andygoncharenco@yahoo.com
}

\begin{abstract}
In this publication a Doctrine for the Conditional Extremization of the Hybrid-Optional Effectiveness Functions Entropy is discussed as a tool for the Reliability Assessments of Engineering Systems. Traditionally, most of the problems having been dealt with in this area relate with the probabilistic problem settings. Regularly, the optimal solutions are obtained through the probability extremizations. It is shown a possibility of the optimal solutions "derivation", with the help of a model implementing a variational principle which takes into account objectively existing parameters and components of the Markovian process. The presence of an extremum of the objective state probability is observed and determined on the basis of the proposed Doctrine with taking into account the measure of uncertainty of the hybrid-optional effectiveness functions in the view of their entropy. Such approach resembles the well known Jaynes' Entropy Maximum Principle from theoretical statistical physics adopted in subjective analysis of active systems as the subjective entropy maximum principle postulating the subjective entropy conditional optimization. The developed herewith Doctrine implies objective characteristics of the process rather than subjective individual's preferences or choices, as well as the states probabilities maximums are being found without solving a system of ordinary linear differential equations of the first order by Erlang corresponding to the graph of the process. Conducted numerical simulation for the proposed mathematical models is illustrated with the plotted diagrams.
\end{abstract}

Keywords: effectiveness functions entropy, hybrid-optional effectiveness, multi-optionality, optimal distribution, variational principle, probability, reliability, entropy maximum principle, optimal periodicity. 


\section{INTRODUCTION}

Scientific investigations in the framework of the physical processes uncertainty often use the Jaynes' entropy maximum principle considered in publications [9-11]. Entropy paradigm is also widely used in the variety of applications starting from those to psychological $[5,8,12-14,21-27]$ theoretical research and ending with engineering $[2-8,13,14,23,24,26,27]$ and economical problems $[4,8,13$, 14, 23-27]. The global trend entropy research seems keep growing according with the reference of [18].

It is an obvious thing that in order to solve properly engineering tasks and research problems on technical operation of engineering systems [1,19] the formal science gives a powerful mathematical apparatus [28-30]. Through centuries it proves the methods effectiveness. Nevertheless, evolution of scientific approaches has no end. It looks prospective to implement the developed Doctrine to the problems discussed in references [31-34] since the recent research [35-49] gives a good background for that.

The objectives of the presented study results are to demonstrate the newly developed Hybrid-Optional Effectiveness Functions Entropy Conditional Extremization Doctrine applicability to the problems of the Engineering Systems Reliability Assessments [2-4, 6, 7].

The example of the theoretical concept contemplations is for an Aircraft Given Functional System Maintenance Process Improvement $[15,20,28]$. However, implementation might be for a system of any kind, subject to considered circumstances, of course. Besides, it is important that hereinafter in the presented paper the developed Doctrine involves the postulated optimality rather than axiomatic statement for the probability of choice likewise in works [21, 22] on the basis of the Luce's axiom [16, 17].

The initial provisions of the presented paper was submitted to the ICEF III, $3^{\text {rd }}$ International Conference on Engineering and Formal Sciences, Amsterdam Science Park, 11-12 May 2018, at https:// euser.org/icef3. But for some reason it was not published yet.

\section{THEORETICAL CONCEPTS}

The cornerstone of the presented research is a statement about the existing optimality of the optional functions in nature engineering $[2-8,13,14,23-27]$. It postulates the optimality of the processes going on within the Markovian systems $[2-4,6,7]$. It deals with the probabilities of states, [28-30]. And it is going to be a generalization for the Markovian systems processes considered in references $[2-4,6,7]$.

\section{PROTOTYPE APPROACHES}

First of all it is entropy paradigm applications in psychology and economics [5, 8, 12-14, 21-27], Jaynes's principle [9-11], and axiomatic of Luce's [16, 17, 21, 22].

\section{VARIATIONAL PRINCIPLE OF PSYCHOLOGY}

In particular, the human psychological behavioral choice factor influence problems are connected with economy, sociology, education, taken into account in engineering, including when safety of such systems is considered [5, 8, 12-14, 21-27]. 


\section{RELIABILITY PROBLEM}

In any case, in order to prove the justifiability (strength, sustainability) of the developed aircraft given functional system maintenance process improvements $[15,20,28]$ it is and has to (should) be given some good reasons in favor of either for the arguments substantiating the advantages of the proposed things $[1,15,19,20,28-30]$.

Therefore, it is unavoidable to introduce certain both qualitative and quantitative values, regularly (generally) accepted as the measures (criteria or indices/indexes), helping construct, describe, and develop mathematical research models. The choice of these criteria or measures does not have to be solely based upon the having been well known or standard values or approaches. The creativity work must be manifested here. Heuristic, challenging task and problem settings are welcome to be developed.

For example, as a result of the Improvement of the Aircraft Given Functional System Maintenance Process some reliability, dependability probabilistic characteristics might be increased, so the corresponding measures might be chosen to demonstrate, prove, substantiate the advantages of the proposed modifications. These are, let us say, for instance, might be the basic probabilistic values (measures) of Reliability, Failure-Free Operation, Durability, Longevity, Maintainability, Storability or any of these measures combinations.

Elements of the mass service theory $[29,30]$ are also can be applied to the reliability problems solving.

For example, considering a Markovian random process with discrete states and continuous time, for a general case with three states we have a graph shown in Fig. 1.

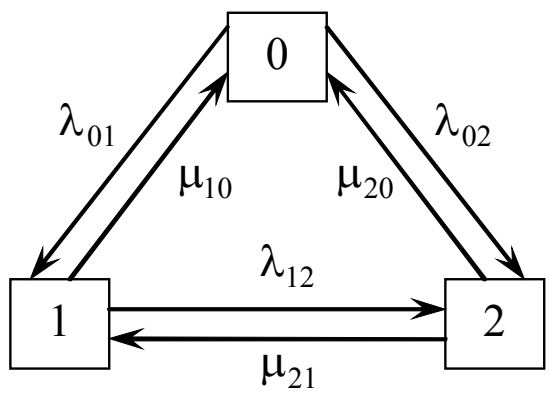

Fig. 1 - Graph of three states of an aircraft functional system

Here, in Fig. 1, "0" designates the up state of the system; "1" - damage; "2" - failure. The corresponding values of the failure rates $\lambda_{\mathrm{ij}}$ and restoration rates $\mu_{\mathrm{ij}}$, deemed to be constant in time $t$, will determine the process going on in the system. For the substantiated reasons, for the state of "2" to be a state without an "exit", it has to be satisfied the conditions of $\mu_{20}=\mu_{21}=0$. Then, it, the state of " 2 ", will be a real failure.

The corresponding, to the graph of Fig. 1, initial matrix $\mathbf{M}$ will have the view of

$$
\mathbf{M}=\left\|\begin{array}{ccc}
p+\left(\lambda_{0}+\lambda_{0}\right) & -\mu_{0} & -\mu_{0} \\
-\lambda_{0} & p+\left(\lambda_{\mathrm{I}}+\mu_{0}\right) & -\mu_{2} \\
-\lambda_{0} & -\lambda_{\mathrm{I}} & p+\left(\mu_{\mathrm{D}}+\mu_{2}\right)
\end{array}\right\|
$$


where $p$ is a parameter (variable) still unknown. The elements of the matrix of (1) symbolize optional transitions of the system from state to state. The rates of going out of the states are taken with the "positive" sign "+", whereas coming into the state with the "negative" sign "-" instead.

In such respect, the considered example may be given an attention to in regards with the help of the Multi-Optional Hybrid-Effectiveness Functions Uncertainty Measure Conditional Optimization Doctrine applicable to the aeronautical engineering optimal maintenance periodicities determination $[2-4,6,7]$. The essence of the doctrine (method, idea, approach, concept) is to consider the process developing in the system from the position of some hybrid optional functions distribution optimality.

Consider the options essential to the system.

The objective functional proposed is as follows:

$$
\begin{gathered}
\Phi_{h}=-\sum_{i=1}^{3}\left[x F_{1}^{(i)}\right] \ln \left[x F_{1}^{(i)}\right]-\frac{t_{p}^{*}}{\lambda_{01}} \sum_{i=1}^{3}\left[x F_{1}^{(i)}\right]\left(M_{12}^{(i)}\right)+\gamma\left[\sum_{i=1}^{3}\left[x F_{1}^{(i)}\right]-1\right] \\
F_{1}^{(i)}=\frac{M_{12}^{(i)}}{\Delta(\mathbf{M})}=\frac{k_{i} \lambda_{01}+c_{1}}{p\left(p^{2}+p e_{1}+b_{1}+c_{1}+d_{1}\right)} \\
k_{12}^{(i)}=\frac{-e_{i} \lambda_{01}+c_{1}, \quad}{2 f_{1}}, \quad k_{2}=\frac{-e_{1}-\sqrt{e_{1}^{2}-4 f_{1} g_{1}}}{2 f_{1}}, \quad k_{3}=0, \\
f_{1}=1, \quad g_{1}=b_{1}+c_{1}+d_{1}, \\
b_{1}=\lambda_{12} \mu_{20}+\mu_{10} \mu_{20}+\mu_{10} \mu_{21}, \quad c_{1}=\lambda_{01} \mu_{20}+\lambda_{01} \mu_{21}+\lambda_{02} \mu_{21} \\
d_{1}=\lambda_{01} \lambda_{12}+\lambda_{02} \lambda_{12}+\lambda_{02} \mu_{10}, \quad e_{1}=\mu_{20}+\mu_{21}+\lambda_{12}+\mu_{10}+\lambda_{01}+\lambda_{02},
\end{gathered}
$$

where $\mathrm{x}$ is an unknown parameter; $\mathrm{h}_{\mathrm{i}}=\mathrm{xF}_{1}{ }^{(\mathrm{i})}$ is the multi-optional hybrid functions depending upon the options effectiveness functions of $\mathrm{F}_{1}^{(\mathrm{i})} ; \mathrm{t}_{\mathrm{p}}^{*} \lambda_{01}$; is the intrinsic parameter of the system and the process, which is the ratio of the optimal (delivering the sought maximal value to the probability) time $t_{p}^{*}$ of the maintenance periodicity, it is unknown yet for such problem formulation and the time of $\mathrm{t}^{*}$ is going to be determined as a solution, to the flow intensity $\lambda_{01 ;} M_{12}^{(i)}$ is the algebraic addition of the initial elementary intensities matrix M, Eq. (1), formed in the style likewise from the Erlang's system [30], element of $\mathrm{m}_{12} ; \gamma$ is the parameter, coefficient, function (uncertain Lagrange multiplier, weight coefficient) for the normalizing condition. 
Consider an extremum existence necessary conditions for the objective functional of (2):

$$
\begin{gathered}
\frac{\partial \Phi_{h}}{\partial h_{i}}=\frac{\partial \Phi_{h}}{\partial\left[x F_{1}^{(i)}\right]}=0, \quad \forall i \in \overline{1,3} . \\
\ln \left[x F_{1}^{(1)}\right]+\frac{t_{p}^{*}}{\lambda_{01}}\left(\lambda_{01} k_{1}+c_{1}\right)=\gamma-1=\ln \left[x F_{1}^{(2)}\right]+\frac{t_{p}^{*}}{\lambda_{01}}\left(\lambda_{01} k_{2}+c_{1}\right) .
\end{gathered}
$$

From where

$$
\ln \left[x F_{1}^{(1)}\right]+\frac{t_{p}^{*}}{\lambda_{01}}\left(\lambda_{01} k_{1}+c_{1}\right)=\ln \left[x F_{1}^{(2)}\right]+\frac{t_{p}^{*}}{\lambda_{01}}\left(\lambda_{01} k_{2}+c_{1}\right)
$$

After that, we have got the law of subjective conservatism [8] on one hand and on the other hand the similar to the traditional probabilistic approach expression, $[2-4,6,7]$ :

$$
\ln \left[x F_{1}^{(1)}\right]-\ln \left[x F_{1}^{(2)}\right]=\frac{t_{p}^{*}}{\lambda_{01}}\left[\left(\lambda_{01} k_{2}+c_{1}\right)-\left(\lambda_{01} k_{1}+c_{1}\right)\right]
$$

At last, we obtain

$$
\ln \left[x F_{1}^{(1)}\right]-\ln \left[x F_{1}^{(2)}\right]=t_{p}^{*}\left[\left(k_{2}+\frac{c_{1}}{\lambda_{01}}\right)-\left(k_{1}+\frac{c_{1}}{\lambda_{01}}\right)\right] .
$$

After that

$$
t_{p}^{*}=\frac{\ln \left[F_{1}^{(1)}(\cdot)\right]-\ln \left[F_{1}^{(2)}(\cdot)\right]}{k_{2}(\cdot)-k_{1}(\cdot)}
$$

And finally with taking into account Eq. (3)-(8)

$$
t_{p}^{*}=\frac{\ln \frac{k_{1} \lambda_{01}+c_{1}}{p\left(p^{2}+p e_{1}+b_{1}+c_{1}+d_{1}\right)}-\ln \frac{k_{2} \lambda_{01}+c_{1}}{p\left(p^{2}+p e_{1}+b_{1}+c_{1}+d_{1}\right)}}{k_{2}(\cdot)-k_{1}(\cdot)} .
$$




$$
t_{p}^{*}=\frac{\ln \left(k_{1} \lambda_{01}+c_{1}\right)-\ln \left(k_{2} \lambda_{01}+c_{1}\right)}{k_{2}(\cdot)-k_{1}(\cdot)}
$$

\section{AN EXAMPLE OF A COMPUTER SIMULATION}

In the developed problem setting, the diagrams plotted by the numerical simulation with the formulae of Eq. (1)-(16) are shown in Fig. 2.

In order to illustrate this point for the example considered (see Fig. 1), the mathematical modeling has been realized for such initial data for the probabilities of the system's corresponding states of "0", " 1 ", and " 2 ": $\left.\mathrm{P}_{0}\right|_{\mathrm{t}=\mathrm{t} 0}=1,\left.\mathrm{P}_{1}\right|_{\mathrm{t}=\mathrm{t} 0}=\left.\mathrm{P}_{2}\right|_{\mathrm{t}=\mathrm{t} 0}, \mathrm{t}_{0}=0$, and other values: $\lambda_{01}=5 \cdot 10^{-3} \mathrm{~h}^{-1} ; \lambda_{02}=2 \cdot 10^{-4} \mathrm{~h}^{-1}$; $\lambda_{12}=1 \cdot 10^{-3} \mathrm{~h}^{-1} ; \mu 1_{0}=1 \cdot 10^{-4} \mathrm{~h}^{-1} ; \mu_{20}=3 \cdot 10^{-5} \mathrm{~h}^{-1} ; \mu_{21}=5 \cdot 10^{-5} \mathrm{~h}^{-1} ; \mathrm{t}=0 \ldots 1.5 \cdot 10^{3} \mathrm{~h}$. to ${ }_{\mathrm{pt}} \approx 393 \mathrm{~h}$ is found with the expression of Eq. (16).

The demonstrated in Fig. 2 designations of $\mathrm{a}_{1}, \mathrm{a}_{0}$ and $\mathrm{a}_{2}$ (see Fig. 2) are for the probabilities of $\mathrm{P}_{1}(\mathrm{t})$, $\mathrm{P}_{0}(\mathrm{t})$ and $\mathrm{P}_{2}(\mathrm{t})$ obtained with the computer simulation for the differential equations system by Erlang related to the corresponding graph shown in Fig. 1. Also, $\mathrm{P}_{1}(\mathrm{t}), \mathrm{P}_{0}(\mathrm{t})$ and $\mathrm{P}_{2}(\mathrm{t})$ are for $\mathrm{P}_{1}(\mathrm{t}), \mathrm{P}_{0}(\mathrm{t})$ and $\mathrm{P}_{2}(\mathrm{t})$ respectively, and $\mathrm{P}_{00}(\mathrm{t})$ is for $\mathrm{P}_{0}(\mathrm{t})$ as well, being plotted after the calculation with the use of the different methods analytical results. Both curves $\mathrm{P}_{00}(\mathrm{t})$ and $\mathrm{P}_{0}(\mathrm{t})$ coincide.

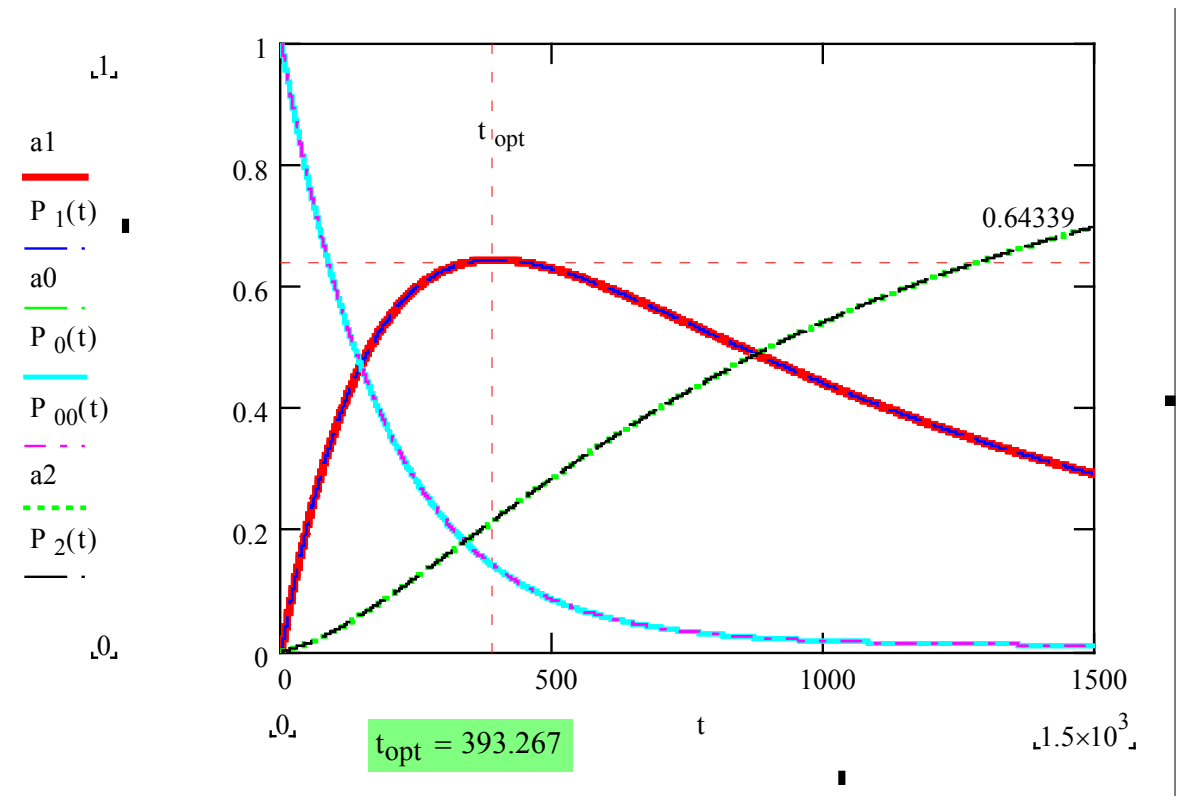

Fig. 2 - Results of the computer calculation experiments conducted with the help of the MathCad standard platform 


\section{DISCUSSION}

Thus, the result of Eq. (16) is obtained in absolutely not probabilistic rather in the Multi-Optional Hybrid-Effectiveness Functions Uncertainty Measure Conditional Optimization Doctrine way, similarly to the approach developed, described, and discussed in references [2-4, 6, 7].

The same approach is applicable to $\mathrm{F}_{2}^{(\mathrm{i})}$ with yielding the parallel to the Eq. (16) results.

Now we ought to say that for the situation when the probability of $\mathrm{P}_{2}(\mathrm{t})$ undergoes the extremum instead of the probability of $\mathrm{P}_{1}(\mathrm{t})$, the problem, due to the symmetry, has a symmetrical solution:

$$
t_{p}^{*}=\frac{\ln \left(k_{1} \lambda_{01}+c_{1}\right)-\ln \left(k_{2} \lambda_{01}+c_{1}\right)}{k_{2}(\cdot)-k_{1}(\cdot)} .
$$

That is the system according to the developing stationary Poison flow process has the possible states optimal options related with either the system of parameters

$$
\left\{k_{i}, \lambda_{02}, d_{1}\right\} \text { or }\left\{k_{i}, \lambda_{01}, c_{1}\right\}
$$

values for the initial moment probability of the state " 0 " being equaled to " 1 ".

The corresponding value of the optimal periodicity $t_{\text {opt }}=393.267$, determined with the expression of Eq. (16), delivering the maximum to the probability of $\mathrm{P}_{1}(\mathrm{t})$, the damage "1", however, being not the failure state "2", on the condition that the probability of the latter state " 2 " $\mathrm{P}_{2}(\mathrm{t})$ does not go beyond (exceed) the accepted level (limit), whereas (while) the up (normal operation conditions) state of the system designated as " 0 " probability: $\mathrm{P}_{0}(\mathrm{t})$ is not lower than the accepted level (limit), is portrayed in Fig. 2; as well as $\left.\mathrm{P}_{1}\right|_{\mathrm{t}=\text { topt }}>0.64339$ and $\left.\mathrm{P}_{2}\right|_{\mathrm{t}=\text { topt }}<0.3,\left.\mathrm{P}_{0}\right|_{\mathrm{t}=\text { topt }}>0.1$ are visible in Fig. 2.

The analogous result is obtained in case of (17) and first of (18).

\section{CONCLUSIONS}

The presented fragments or sections of sciences finished the process of their centralization; they contain at their core some principle of optimality. The multi-optional hybrid functions are mathematically derived in the explicit expression views. That delivers a plausible explanation of a theorem rather than axiom type. There is a hope that such a provision exists, and not occasionally, and not only in the considered problems.

At this, it was shown a possibility of a "derivation", from a variational principle which takes into account the uncertainty measure in the view of the multi-optional hybrid effectiveness functions entropy, of the aircraft given functional system maintenance process optimal periodicity on conditions of acceptable levels of the probabilities of the system's up and failure states. 


\section{REFERENCES}

[1] Dhillon B. S. Maintainability, maintenance, and reliability for engineers / B. S. Dhillon. - New York: Taylor \& Francis Group, 2006. - 214 p.

[2] Goncharenko A. V. A hybrid approach to the optimal aeronautical engineering maintenance periodicity determination / A. V. Goncharenko // Proceedings of the NAU. - 2017. - № 3(72). - pp. 42-47.

[3] Goncharenko A. V. Aeronautical engineering maintenance periodicity optimization with the help of subjective preferences distributions / A. V. Goncharenko / Proceedings of the NAU. - 2017. - vol. 2(71). - pp. 51-56.

[4] Goncharenko A. V. Aircraft Operation Depending upon the Uncertainty of Maintenance Alternatives / A. V. Goncharenko // Aviation. - 2017. Volume 21(4). - pp. 126-131. (ISSN 16487788 / eISSN 1822-4180) doi:10.3846/16487788.2017.1415227; http://www.tandfonline.com/ doi/abs/10.3846/16487788.2017.1415227

[5] Goncharenko A. V. An Alternative Method of the Main Psychophysics Law Derivation / A. V. Goncharenko // Clin. and Exp. Psychol. - 2017. - 3: 155. - pp. 1-5. doi: 10.4172/24712701.1000155. (ISSN: 2471-2701) https://www.omicsonline.org/open-access/an-alternative-method-of-the-main-psychophysics-law-derivation-2471-2701-1000155.pdf

[6] Goncharenko A. V. Optimal managerial and control values for active operation / A. V. Goncharenko // Electronics and control systems. - 2016. - vol. 3(49). - pp. 112-115.

[7] Goncharenko A. V. Optimal UAV Maintenance Periodicity Obtained on the Multi-Optional Basis / A. V. Goncharenko // 2017 IEEE 4 ${ }^{\text {th }}$ International Conference "APUAVD” Proceedings. October, 17-19, 2017, Kyiv, Ukraine. - 2017. - pp. 65-68.

[8] Goncharenko A. V. Some identities of subjective analysis derived on the basis of the subjective entropy extremization principle by Professor V. A. Kasianov / A. V. Goncharenko // Automatic Control and Information Sciences. - 2014. - Vol. 2, No. 1. - pp. 20-25.

[9] Jaynes E. T. Information theory and statistical mechanics / E. T. Jaynes // Physical review. - U.S.A. - 1957. - Vol. 106, № 4. - pp. 620-630.

[10] Jaynes E. T. Information theory and statistical mechanics. II / E. T. Jaynes // Physical review. - U.S.A. - 1957. - Vol. 108, № 2. - pp. 171-190.

[11] Jaynes E. T. On the rationale of maximum-entropy methods / E. T. Jaynes // Proceedings of the IEEE. - 1982. - Vol. 70. - pp. 939-952.

[12] Jing Ch. An Entropy Theory of Psychology and its Implication to Behavioral Finance. [Online]. Available at Social Science Research Network: http://ssrn.com/abstract=465280 or http://dx.doi. org/10.2139/ssrn.465280. [Accessed Sept. 7, 2014].

[13] Kasianov V. Subjective entropy of preferences. Subjective analysis: monograph / V. Kasianov. - Warsaw, Poland: Institute of Aviation Scientific Publications, 2013. - 644 p. (ISBN 978-8363539-08-5)

[14] Kasianov V. A. Extremal Principle of Subjective Analysis. Light and Shadow. Proportions of Shadow Economy. Entropy Approach: monograph / V. A. Kasianov, A. V. Goncharenko. - Kyiv, Ukraine: Kafedra, 2017. - 90 p. (ISBN 978-617-7301-41-6)

[15] Kroes M. J. Aircraft maintenance and repair: $7^{\text {th }}$ ed. / M. J. Kroes, W. A. Watkins, F. Delp, R. Sterkenburg. - New York, USA, McGraw-Hill, Education, 2013. - 736 p.

[16] Luce R. D. Conditional Expected Utility / R. D. Luce, D. H. Krantz // Econometrica. - 1971. - № 39.- pp. 253-271. 
[17] Luce R. D. Individual Choice Behavior: A Theoretical Analysis / R. D. Luce. - Mineola, N. Y: Dover Publications, 2014. - 153 p.

[18] Ma F. C. Study on Global Science and Social Science Entropy Research Trend / F. C. Ma, P. H. Lv, M. Ye // 2012 IEEE fifth international conference on advanced computational intelligence (ICACI), October 18-20, 2012. - Nanjing, Jiangsu, China, 2012. - pp. 238-242.

[19] Smith D. J. Reliability, maintainability and risk. Practical methods for engineers / D. J. Smith. - London: Elsevier, 2005. - 365 p.

[20] Wild T. W. Aircraft powerplants: $8^{\text {th }}$ ed. / T. W. Wild, M. J. Kroes. - New York, New York, USA: McGraw-Hill, Education, 2014. - 756 p.

[21] Zamfirescu C. B. On investigating the cognitive complexity of designing the group decision process / C. B. Zamfirescu, L. Duta, B. Iantovics // Studies in Informatics and Control. - 2010. - Vol. 19, № 3. - pp. 263-270.

[22] Zamfirescu C. B. The cognitive complexity in modelling the group decision process / C. B. Zamfirescu, L. Duta, B. Iantovics. [Online]. Available: http://ssd.valahia.ro/UICS.pdf. [Accessed Sept. 27, 2014].

[23] Касьянов В. А. Элементы субъективного анализа: монография / В. А. Касьянов. - К.: НАУ, 2003. - 224 c. [Kasianov V. A. Elements of Subjective Analysis: monograph / V. A. Kasianov. - Kyiv, Ukraine: National Aviation University, 2003. - 224 p. (in Russian)]

[24] Касьянов В. А. Субъективный анализ: монография / В. А. Касьянов. - К.: НАУ, 2007. - 512 c. [Kasianov V. A. Subjective Analysis: monograph / V. A. Kasianov. - Kyiv, Ukraine: National Aviation University, 2007. - 512 p. (in Russian)]

[25] Касьянов В. А. Свет и тень. Пропорции теневой экономики. Энтропийный подход: монография / В. А. Касьянов, А. В. Гончаренко. - К.: Кафедра, 2013. - 86 с. (ISBN 978-9662705-36-2) http://media.wix.com/ugd/4dca65_03519cc3da494c3cb415ecb94f88ac77.pdf [Kasianov V. A. Light and Shadow. Proportions of Shadow Economy. Entropy Approach: monograph / V. A. Kasianov, A. V. Goncharenko. - Kyiv, Ukraine: Kafedra, 2013. - 86 p. (in Russian)]

[26] Касьянов В. А. Вариационные принципы субъективного анализа. Модифицированный вариационный принцип Эйлера-Аагранжа. Энтропийный подход: монография / В. А. Касьянов, А. В. Гончаренко. - К.: АП НВЦ «Приорітети», 2015. - 112 с. (ISBN 978-966-880967-5) http://media.wix.com/ugd/4dca65_c80b9fde57744e018ada21ecd32ca678.pdf [Kasianov V. A. Variational Principles of Subjective Analysis. Modified Euler-Lagrange Variational Principle. Entropy Approach: monograph / V. A. Kasianov, A. V. Goncharenko. - Kyiv, Ukraine: SE TPC "Pryoritety", 2015. - 112 p. (in Russian)]

[27] Касьянов В. А. Энтропийная парадигма в теории активных систем. Субъективный анаАиз: монография / В. А. Касьянов. - К.: АП НВЦ «Приорітети», 2016. - 657 с. (ISBN 978-6177288-11-3) [Kasianov V. A. Entropy Paradigm in the Theory of Active Systems. Subjective Analysis: monograph / V. A. Kasianov. - Kyiv, Ukraine: SE TPC "Pryoritety", 2016. - 657 p. (in Russian)]

[28] Техническая эксплуатация метательных аппаратов: учебник Аля вузов / под реА. Н. Н. Смирнова. - М.: Транспорт, 1990. - 423 с. [Technical operation of aircraft: study-book for higher education institutions / edited by N. N. Smirnov. - Moscow, USSR: Transport, 1990. - 423 p. (in Russian)]

[29] Гнеденко Б. В. Введение в теорию массового обслуживания / Б. В. Гнеденко, И. Н. Коваменко. - M.: URSS, 2013. - 400 с. [Gnedenko B. V. Introduction into the mass service theory / B. V. Gnedenko, I. N. Kovalenko. - Moscow, Russia: URSS, 2013. - 400 p. (in Russian)] 
[30] Овчаров $\Lambda$. А. Прикладные задачи теории массового обслуживания / $\Lambda$. А. Овчаров. - М.: Машиностроение, 1969. - 324 с. [Ovcharov L. A. Applicable problems of the theory of mass service / L. A. Ovcharov. - Moscow, USSR: Machinebuilding, 1969. - 324 p. (in Russian)]

[31] Kasjanov V., Szafran K., Some hybrid models of subjective analysis in the theory of active systems, "Transactions of the Institute of Aviation", 2015, 3(240), 27-31.

[32] Pagowski Z. T., Szafran K., "Ground effect" inter-modal fast sea transport, "The International Journal on Marine Navigation and Safety of Sea Transportation", 2014, 8(2), 317-320.

[33] Szafran K., Bezpieczeństwo lotu - zasada maksymalnej entropii, "Bezpieczeństwo na Lądzie, Morzu i w Powietrzu w XXI Wieku", 2014, 1, 247-251.

[34] Szafran K., Kramarski I., Safety of navigation on the approaches to the ports of the republic of Poland on the basis of the radar system on the aerostat platform, "International Journal on Marine Navigation and Safety of Sea Transportation”, 2015, 9(1), 129-134.

[35] Goncharenko A. V. Active Systems Communicational Control Assessment in Multi-Alternative Navigational Situations / A. V. Goncharenko // 2018 IEEE $5^{\text {th }}$ International Conference "Methods and Systems of Navigation and Motion Control (MSNMC)" Proceedings. - October, 16-18, 2018, Kyiv, Ukraine. - 2018. - pp. 254-257.

[36] Goncharenko A. V. Development of a theoretical approach to the conditional optimization of aircraft maintenance preference uncertainty / A. V. Goncharenko // Aviation. - 2018. Volume 22(2). - pp. 40-44. (ISSN 1648-7788 / eISSN 1822-4180) https://doi.org/10.3846/aviation.2018.5929.

[37] Goncharenko A. V. A multi-optional hybrid functions entropy as a tool for transportation means repair optimal periodicity determination / A. V. Goncharenko // Aviation. - 2018. Volume 22(2). - pp. 60-66. (ISSN 1648-7788 / eISSN 1822-4180) https://doi.org/10.3846/aviation.2018.5930.

[38] Goncharenko A. V. Multi-Optional Hybrid Effectiveness Functions Optimality Doctrine for Maintenance Purposes / A. V. Goncharenko // 14th IEEE International Conference on Advanced Trends in Radioelectronics, Telecommunications and Computer Engineering (TCSET-2018). - February 20-24, 2018. - Lviv-Slavske, Ukraine, 2018. - pp. 771-775.

[39] Goncharenko A. V. An Entropy Model of the Aircraft Gas Turbine Engine Blades Restoration Method Choice / A. V. Goncharenko // International Conference on Advanced Computer Information Technologies (ACIT-2018). - June 1-3, 2018. - Ceske Budejovice, CZECH REPUBLIC, 2018. - pp. 2-5.

[40] Goncharenko A. V. Aeronautical and Aerospace Material and Structural Damages to Failures: Theoretical Concepts / A. V. Goncharenko // International Journal of Aerospace Engineering. - Volume 2018 (2018), Article ID 4126085, 7 pages https://doi.org/10.1155/2018/4126085; 2018. - pp. 1-7.

[41] Goncharenko A. V. Airworthiness Support Measures Analogy to the Prospective Roundabouts Alternatives: Theoretical Aspects / A. V. Goncharenko // Journal of Advanced Transportation. - Volume 2018 (2018), Article ID 9370597, 7 pages https://doi.org/10.1155/2018/9370597; 2018. - pp. 1-7.

[42] Goncharenko A. V. Several Models of Artificial Intelligence Elements for Aircraft Control / A. V. Goncharenko // 2016 IEEE $4^{\text {th }}$ International Conference "Methods and Systems of Navigation and Motion Control (MSNMC)” Proceedings. - October, 18-20, 2016, Kyiv, Ukraine. - 2016. - pp. 224-227.

[43] Goncharenko A.V. Applicable Aspects of Alternative UAV Operation / A.V. Goncharenko // 2015 IEEE $3^{\text {rd }}$ International Conference "Actual Problems of Unmanned Aerial Vehicles Developments (APUAVD)” Proceedings. - October, 13-15, 2015, Kyiv, Ukraine. - 2015. - pp. 316-319. 
[44] Goncharenko A.V. Navigational Alternatives, Their Control and Subjective Entropy of Individual Preferences / A.V. Goncharenko // 2014 IEEE $3^{\text {rd }}$ International Conference "Methods and Systems of Navigation and Motion Control (MSNMC)" Proceedings. - October, 14-17, 2014, Kyiv, Ukraine. - 2014. - pp. 99-103.

[45] Goncharenko A.V. Expediency of unmanned air vehicles application in the framework of subjective analysis / A.V. Goncharenko // 2013 IEEE $2^{\text {nd }}$ International Conference "Actual Problems of Unmanned Air Vehicles Developments" Proceedings. - October, 15-17, 2013, Kyiv, Ukraine. - 2013. - pp. 129-133.

[46] Goncharenko A. V. Optimal controlling path determination with the help of hybrid optional functions distributions / A. V. Goncharenko // Radio Electronics, Computer Science, Control. - 2018. - № 1(44). - pp. 149-158. (ISSN 1607-3274 (print), ISSN 2313-688X (on-line)) DOI 10.15588/1607-3274-2018-1-17 https://drive.google.com/open?id=1 LwU7WEl6yle417oeTDZAdVJ7vIzkOldu

[47] Continuing Aircraft Airworthiness (ICAO Doc 9760) : Self-Study Method Guide . Part II . Application of the Multi-Optional Functions Entropy Doctrine to Assess the Aircraft Maintenance Process Improvements / compiler: A. V. Goncharenko. - K. : NAU, 2018. - 48 p. http://er.nau. edu.ua/handle/NAU/35891

[48] Continuing Aircraft Airworthiness (ICAO Doc 9760) : Self-Study Method Guide . Part I . Reliability Measures to Assess the Aircraft Maintenance Process Improvements / compiler: A. V. Goncharenko. - K. : NAU, 2018. - 48 p. http://er.nau.edu.ua/handle/NAU/35890

[49] Continuing Aircraft Airworthiness (ICAO Doc 9760) : Term Paper Method Guide / compiler: A. V. Goncharenko. - K. : NAU, 2018. - 48 p. http://er.nau.edu.ua/handle/NAU/35889 